\title{
The Relationship between Transpiration and Calcium Fertilization on Mangosteen (Garcinia mangostana L.) Seedlings
}

\author{
Ajmir Akmal1', Edi Santosa², Roedhy Poerwanto², Ismadi Yunus ${ }^{3}$, Rd Selvy Handayani3 \\ ${ }^{1}$ Department of Agricultural Industrial Technology, Faculty of Agriculture, Universitas Al Muslim. Bireuen, Indonesia \\ ${ }^{2}$ Department of Agronomy and Horticulture, Faculty of Agriculture, Bogor Agricultural University, Bogor 16680, Indonesia \\ ${ }^{3}$ Department of Agroecotechnology, Faculty of Agriculture, Universitas Malikussaleh, Aceh Utara, Indonesia \\ *Corresponding author: ajmir.akmal@gmail.com
}

\section{ARTICLE HISTORY \\ Received : 12 August 2018 \\ Revised : 21 August 2018 \\ Accepted : 15 September 2018}

\section{KEYWORDS}

Leaves

Calcium effectiveness

Mangosteen

Transpiration

\begin{abstract}
The availability of nutrients in plants depends on the ability of plants to absorb nutrients from the soil One of the processes absorbed by plants is by the presence of the transpiration process. Good transpiration will provide enough nutrients for plants which increase the productivity and quality of mangosteen. One of the quality standards of mangosteen fruit for export quality is the free from yellow sap contamination. It can be possible that transpiration can improve the quality of mangosteen fruit by applying fertilization. In this study Ca fertilization was carried out on mangosteen seeds, where this study aims to investigate the effectiveness of Ca uptake by mangosteen plants with the level of water loss by transpiration. This research was conducted in November 2016 - March 2017 at the Leuwikopo Experimental Garden, Bogor Agricultural University. Morphological observations were carried out in its Experimental Garden and the Postharvest Laboratory while analysis of calcium content of plant tissue was done at the Department of Agronomy and Horticulture, Bogor Agricultural University. Data obtained then were analyzed using ANOVA test. If the results were significant, Duncan Multiple Range Test (DMRT) was then tested at 0.05 probability level. The results revealed that the transpiration rate of mangosteen plants from several treatments showed a significant difference, the transpiration rate was higher, especially in fertilized plants. The size of the $12^{\text {th }}$ leaf, plants treated with fertilizer have a larger size than the treatment without fertilization. Fertilizing and providing enough water can maintain the growth of the plants.
\end{abstract}

\section{INTRODUCTION}

The availability of nutrients in plants depends on the ability of plants absorbing nutrients in the soil. Besides, the fulfillment of elements by plants can provide good quality in plants. One of the processes absorbed by plants is by the presence of the transpiration process. Good transpiration will provide enough nutrients for plants which in turn can increase the productivity and quality of mangosteen fruit. Transpiration plays an important role in the process of metabolism and provides important benefits for plants (Irwanto, 2013).

Mangosteen (Garcinia mangostana L.) is one of the most admired tropical fruit and known widely as the Queen of Fruits for its beautiful purple blue pericarp and delicious flavor. The edible aril is white, soft and juicy with sweet taste. The fruit pericarp also contains many chemical compounds that have possible medicinal value andit also has good prospect to be developed as an export commodity. The quality of mangosteen fruit is diverse due to various production centers still run the product and management traditionally. One of the quality standards of mangosteen fruit for export quality is that it frees from yellow sap contamination. It can be possible that transpiration can improve the quality of mangosteen fruit by applying fertilizer. Yellow sap contamination in mangosteen causes quality deterioration. The presence of yellow sap on this exotic fruit can undermine the color and taste.

This yellow sap that commonly called 'gamboge' is latex produced in all parts of the mangosteen plant and it can spread to the flesh and skin of the fruit if the yellow sap channel is broken which caused by the changes in water availability and extreme soil moisture. The rupture of the sap can affect the appearance, taste and quality of the mangosteen fruit itself. The rupture of the yellow sap can be caused by differences in the growth rate between seeds and aryl with pericarp during the fruit enlargement phase 
which results in mechanical pressure from the seeds and aryl to the pericarp (Poerwanto et al., 2010). Several hypotheses have been concluded that the causes of yellow sap such as changes in plant turgor, lack of macro nutrients, calcium deficiency (Purnama, 2013), groundwater fluctuations (Irwanto, 2013) and other physiological factors. According to Dorly (2009), application of Ca has been carried out to prevent yellow sap contamination and increase the Ca content in exocarp, however, application of $\mathrm{Ca}$ which under unsuitable conditions and time is ineffective.

The application of $\mathrm{Ca}$ at flowering time cannot increase the calcium in the fruit but it does increase the Calcium content in the leaves (Dorly, 2009). The application of $\mathrm{Ca}$ at the time of anthesis is important to get the optimum effect in reducing yellow latex on the fruit because it is the beginning of fruit development (Poovarodom, 2009). Ca is an immobile element in plants and moves in xylem mostly through the help of water transpiration (Bangerth, 1979; Gardner et al., 1991). Transpiration is the loss of moisture from plants through stomata (Tjondronegoro et al., 1999), whose rate is influenced by environmental and genetic factors (Hutasoit and Dewi, 2006). In this study, Ca fertilization was applied on mangosteen seeds. The purpose of this study is to investigate the effectiveness of calcium uptake by mangosteen plants with the level of water loss by the transpiration.

\section{MATERIALS AND METHODS}

This research was conducted in November 2016 - March 2017 at the Leuwikopo Experimental Garden. Morphological observations were carried out in the experimental garden and the Postharvest Laboratory, Bogor Agricultural University and analysis of calcium content of plant tissue was done at the Department of Agronomy and Horticulture, Bogor Agricultural University.

The materials used in this study were mangosteen seeds from 2-year-old seedlings. The seedlings then were planted in $10 \mathrm{~kg}$ polybags with compost and soil as a medium. The tools used were a thermometer, Atomic Absorption Spectrophotometry (AAS) for calcium analysis, LICOR 3000, scales, cameras, ovens, and anemometers to measure wind speed.

This research used a Randomized Block Design (RBD) with 3 different treatments: seeds fertilized with $\mathrm{Ca}$, seeds without Ca fertilization and flushes with Ca application. Each treatment was replicated 3 times and each of treatment consisted of 3 mangosteen seeds.

\subsection{Research Procedures}

\subsubsection{Mangosteen seedlings}

The seeds were planted in polybags and placed directly in the field exposed to the sun. Commercial seedlings are moved into polybags to homogenize the growing media. When it rains, the plants were transferred to the bottom of a plastic bowl to avoid rainwater. Plastic pot size $30 \mathrm{~cm} \times$ $40 \mathrm{~cm} \times 20 \mathrm{~cm}$. Treatment started 3 weeks after polybag replacement.

\subsubsection{Measurement of field capacity and watering time}

Field capacity measurement is done to determine the watering volume. The planting medium was doused with water until it was saturated and there were no more droplets from the pot hole. This watering was applied daily in the morning at $6 \mathrm{AM}$. Before watering the plants, the plants in pots needed to be weighed to measure its dry weight. The wet weight of the media was weighed after watering, to determine the watering water weight. The pot is again weighed In the afternoon to calculate the water evaporated between 6 AM-5 PM. The control (polybag without plants) was used to calculate evaporation.

\subsubsection{Dolomite (Ca) fertilization}

The application of calcium in the form of dolomite is done on mangosteen after replacement. The dolomite dose given was $25 \mathrm{~g} /$ seedling tree.

\subsubsection{Plant maintenance}

The maintenance was done regularly. Weeds were controlled and cleaned manually. During the experiment, no additional fertilizer was applied.

\subsection{Data Observations}

\subsubsection{Plant height}

Plant height observations were done by measuring plant height at the beginning of treatment and at the end of the treatment (in meters). The number of leaves was observed at the beginning and the end of the study was to calculate the number of leaves both at the start and the end of experiments.

\subsubsection{Leaf area}

Leaf area was measured using LICOR 3000.

\subsubsection{Water loss rate}

Observation of the level of water loss is done by weighing all the treatment plants before the plants were watered and weighed in the afternoon.

\subsubsection{Morphology of leaves}

Changes in leaf morphology observed included wilting leaves, changes in color and other morphological changes.

\subsubsection{Root length}

Root length measurements were carried out at the end of the experiments after the plants were removed from the pots, which was 4 months after the replacement. The roots were cleaned from the planting medium by soaking the roots together with the rest of the soil into water. The measurement was done after the root was cleaned from the planting medium.

\subsubsection{Wet weight of roots and leaves}

Wet weight of roots and leaves was measured by weighing the roots and leaves at the end of the experiments. 


\subsubsection{Dry weight of roots and leaves}

Measurement of dry weight of roots and leaves was done after the roots and leaves were in the oven for 3 days with a temperature of $80^{\circ} \mathrm{C}$.

\subsection{Data Statistical Analysis}

The data calculated was analyzed by Analysis of Variance (ANOVA) at 0.05 probability level, where significant differences existed means were then separated using Duncan's Multiple Range Test (DMRT).

\section{RESULTS AND DISCUSSION}

\subsection{Results}

\subsubsection{Transpiration and Plant Growth}

The transpiration rate of mangosteen plants from several treatments showed significant differences (Table 1). The transpiration rate was higher in treated plants. The application of fertilizer can stimulate the growth of plants well so that the absorption of water is higher than plants without fertilization.

Table 1. Transpiration, number of leaves, plant height, leaf width, and leaf wet weight at 3 months after transplanting

\begin{tabular}{lccccc}
\hline Treatments & $\begin{array}{c}\text { Transpiration } \\
\left(\mathrm{mol} \mathrm{H}_{2} \mathrm{O}_{\mathrm{s}} \mathrm{s}^{-}\right)\end{array}$ & Number of leaf & Plant height $(\mathrm{cm})$ & Leaf width $\left(\mathrm{cm}^{2}\right)$ & $\begin{array}{c}\text { Leaf wet weight } \\
(\mathrm{g})\end{array}$ \\
\hline Seeds with Ca & $0.44 \mathrm{a}$ & $18.7 \mathrm{ab}$ & $40.33 \mathrm{~b}$ & $61.14 \mathrm{a}$ & $44.92 \mathrm{ab}$ \\
Seeds without Ca & $0.38 \mathrm{ab}$ & $15.7 \mathrm{~b}$ & $40.50 \mathrm{~b}$ & $53.91 \mathrm{a}$ & $36.38 \mathrm{~b}$ \\
Flush with Ca & $0.39 \mathrm{~b}$ & $30.7 \mathrm{a}$ & $55.67 \mathrm{a}$ & $66.62 \mathrm{a}$ & $55.38 \mathrm{a}$ \\
& $*$ & $*$ & $* *$ & & $* *$
\end{tabular}

The means in the same columns followed by the same letters do not differ significantly (P $\leq 0.05)$ as determined by Duncan's multiple range tests. ${ }^{*}$ significant at $\alpha 5 \%$; ${ }^{* *}$ significant at $\alpha 1 \%$;

The number of leaves, plant height and leaf wet weight showed significant differences between treatments (Table 1), where the flush had higher leaves, plant height and wet weight than other treatments. The transpiration rate had a positive correlation with leaf area. The larger the size of the leaf, the greater the transpiration rate (Karti, 2010). Fertilizer is also considered to accelerate the growth of leaves, so that the process of leaf development was also faster in plants treated plants (Figure 1). The size of the $12^{\text {th }}$ leaf, plants treated with fertilizer have a larger size than the treatment without fertilization. The finding of Helmi (2007) reported that the interaction between the type and concentration of fertilizer on leaves had an influence on the number of leaves. According to Kurniadinata (2010), the treatment of nitrogen, phosphorus and potassium fertilizers for 5 years increased the growth and production of mangosteen. The results of research done by Elni (2016) also revealed that the ratio of planting material affected the growth of the seeds. The implementation of $\mathrm{P}$ fertilizer affected the growth of mangosteen seeds, especially plant height, branch length, number of branches and number of leaves (Lukman, 2010).

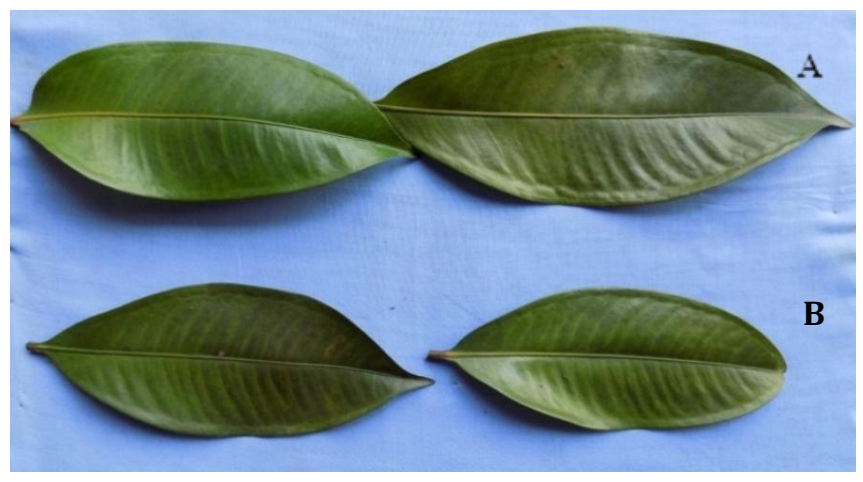

Figure 1. Appearance of the $12^{\text {th }}$ leaf (seedling phase) with fertilizer (A) and without fertilizer (B).

\subsubsection{Root Length, Wet Weight, and Dry Weight}

Table 2 showed no significant differences in wet weight and dry weight of leaves between treatments. The application of $\mathrm{Ca}$ accelerated the growth of mangosteen seeds. As expected, the growth of treated plant roots was very different compared to untreated plant roots. Plants with fertilizer had a large number of roots and also extensive root length, whereas without Ca application, the number of roots was small but had a longer single root (Figure 2).

Table 2. Root length, root wet weight, and dry root weight of mangosteen

\begin{tabular}{llll}
\hline Treatments & $\begin{array}{l}\text { Length } \\
(\mathrm{cm})\end{array}$ & $\begin{array}{l}\text { Wet Weight } \\
(\mathrm{g})\end{array}$ & Dry Weight $(\mathrm{g})$ \\
\hline Seeds with $\mathrm{Ca}$ & $35.00 \mathrm{a}$ & $19.02 \mathrm{a}$ & $7.337 \mathrm{a}$ \\
Seeds without Ca & $46.67 \mathrm{a}$ & $12.69 \mathrm{a}$ & $5.640 \mathrm{a}$ \\
Flushes with Ca & $33.67 \mathrm{a}$ & $14.12 \mathrm{a}$ & $3.137 \mathrm{a}$
\end{tabular}

The means in the same columns followed by the same letters do not differ significantly $(P \leq 0.05)$ as determined by Duncan's multiple range tests.

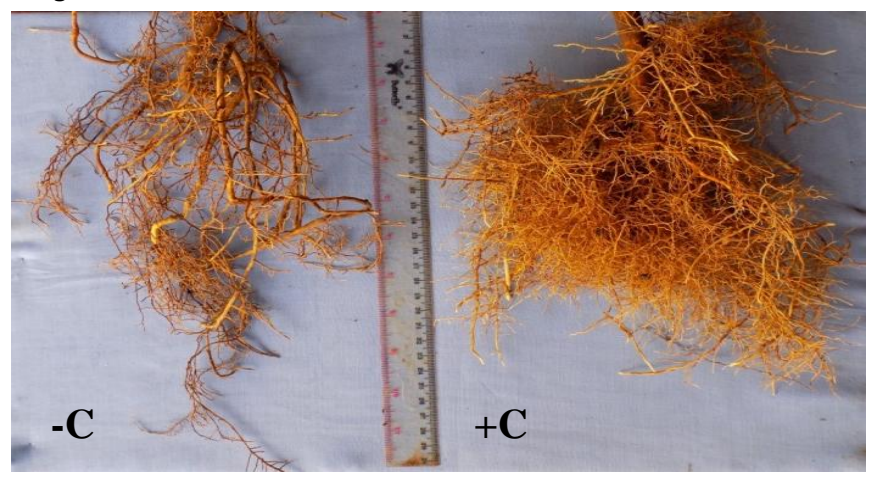

Figure 2. The young phase of the mangosteen root (seedlings) without Ca fertilizer (left) and with Ca fertilizer (right) 


\subsubsection{Water Consumption}

Water nutrient uptake and water loss in each treatment was not significantly different in each treatment, but it was different in the amount of water uptake and water loss in plants daily (Table 3). The level of water loss in plants through the transpiration was also different in each condition and stage of plant growth.

Table 3. Level of water loss (liters) 10 days after plants watering

\begin{tabular}{lllllllllll}
\hline Treatments & Day 1 & Day 2 & Day 3 & Day 4 & Day 5 & Day 6 & Day 7 & Day 8 & Day 9 & Day 10 \\
\hline Treated plants & 0.50 & 0.40 & 0.46 & 0.69 & 0.53 & 0.32 & 0.45 & 0.42 & 0.34 & 0.32 \\
Untreated plants & 0.22 & 0.38 & 0.45 & 0.43 & 0.30 & 0.47 & 0.34 & 0.60 & 0.28 & 0.41 \\
Treated flushes & 0.16 & 0.27 & 0.43 & 0.42 & 0.42 & 0.47 & 0.55 & 0.30 & 0.37 & 0.55 \\
\hline
\end{tabular}

The application of $\mathrm{Ca}$ at flowering time did not increase calcium content in the fruit, but it increased the calcium in the leaves (Dorly, 2009) Ca is an immobile element in plants and moves in xylem mostly through the help of pulling transpiration water (Bangerth 1979; Gardner et al.1991). This present study aims to analyze the effectiveness of Ca uptake by mangosteen plants with the level of water loss by the transpiration. Table 3 above described that the application of Ca did not affect the levels of water at all.

\subsection{DISCUSSION}

The content of $\mathrm{Ca}$ in leaves and fruit is also very influential with the level of Ca uptake to the leaves and fruit. The more leaves grew it decreased the level of Ca in fruit. It is assumed that $\mathrm{Ca}$ is more rapidly obtained by the leaves of plants. This allowed an effort for a good cultivation to regulate the leaves and fruit so that the Ca-application can be optimized to improve fruit quality. The rate of transpiration in fertilized plants was higher than unfertilized plants. The availability of sufficient Ca in plants enabled plants to grow well so that the process of water absorption by plants is more optimal. In the growth of the number of leaves is also essential on the rate of transpiration. The more leaves produced by plants, the level of the transpiration process was also very high. The rate of transpiration was closely related to leaf area. The plants with larger leaves had higher transpiration rate. The application of $\mathrm{Ca}$ in the seedling can affect the number of leaves, plant height and wet weight of leaves. But it did not affect the length, the wet weight and the dry wet of roots. The $12^{\text {th }}$ leaf size in plants treated with fertilizer had a larger size than the treatment without Ca. However, treated plants had longer roots than without application of fertilizer.

The amount of water uptake by plants is no difference in absorption. But the level of water loss by plants is very different in every environmental condition. In environmental conditions with high levels of sunlight the level of water loss is also higher. In the study three water losses in plants were relatively the same. Plant age is also closely related to the level of water loss this is due to the need for water by adult gardens is higher than young plants which has implications for the level of water loss.

\section{CONCLUSION}

The sufficiency of $\mathrm{Ca}$ in soil through fertilization can stimulate the growth of mangosteen. The application of $\mathrm{Ca}$ on the seeds gives positive effect to mangosteen, which enables mangosteen to grow the leaves faster. Fertilization and adequate water supply can maintain the growth of mangosteen.

\section{REFERENCES}

Bangerth, F. 1979. Calcium-relatid physiologycal disorder of plants. Phytophatol. 17: 97-122.

Dorly. 2009. Studi struktur sekretori getah kuning dan pengaruh kalium terhadap cemaran getah kuning pada manggis (Garcinia mangostana L.) [Dissertation]. Bogor Agricultural University. Bogor.

Elni D.2016. Pengaruh rasio tanah dan pupuk kandang sapi sebagai media tanaman terhadap bibit manggis (Garcinia mangostana L.). [Tesis]. Universitas Andalas. Padang.

Gardner, F.P., R. B. Pearce, R. G. Mitchell. 1991. Physiology of Crop Plant. Terjemahan. H. Susilo. Fisiologi Tanaman Budidaya. UI Press. Jakarta.

Helmi. 2007. Pertumbuhan bibit manggis pada beberapa jenis dan kosentrasi pupuk daun. [Thesis]. Faculty of Agriculture. Universitas Bengkulu. Bengkulu.

Hutasoit SN, Dewi PS. 2006. Pengaruh media tanam dan anti transpirasi selama pengangkutan terhadap daya tahan bibit manggis (Garcinia mangostana). [Essay]. Departement of Hortikulture, Faculty of Agriculture. Bogor Agricultural University. Bogor.

Irwanto. 2013. Aplikasi cycocel dalam pengendalian getah kuning buah manggis (Garcinia mangostana L.) pada lahan kering. Lahan Suboptimal. 2 (2): 111-117.

Karti, P. 2010. Pengaruh pemberian cendawan mikoriza arbuskula terhadap pertumbuhan dan produksi rumput Setaria splendida Stapf yang mengalami cekaman kekeringan. Media Peternakan. 27. 2.

Kurniadinata, O. F. 2010. Determinasi status hara N, P, K, pada jaringan daun untuk rekomendasi pemupukan dan prediksi produktivitas manggis. [Thesis]. Bogor Agricultural University. Bogor.

Lukman, L. 2010. Efek Pemberian fosfor terhadap pertumbuhan dan status hara pada bibit manggis. Jurnal Hortikultura. 20 (1):18-26.

Purnama, T. 2013. Pemberian kalium dan boron untuk pengendalian cemaran getah kuning pada buah manggis (Garcinia mangostana L.). [Dissertation]. Bogor Agricultural University. Bogor.

Poerwanto, R., Dorly, M. Maad. 2010. Getah kuning pada buah manggis. [Proceeding]. Seminar Nasional Hortikultura Indonesia, Bali, 25-26 Nopember 2010. Indonesia. p. 255-259.

Tjondronegoro, P. D., S. Harran, Hamin. 1999. Fisiologi Tumbuhan Dasar Jilid I. Departement of Biology. Jurusan Biologi, Faculty of 
Mathematics and Natural Sciences. Bogor Agricultural University. Bogor. P.118. Bogor.

Poovarodom, Sumitra. 2009. Growth and nutrient upteke into manggosteen (Garcinia mangostana L.) fruit. [Proceeding]. The Internasional Plant Nutrition Colloqium XVI. 15 April 2009. 